33. Субтельний О. Україна. Історія / О. Субтельний. - Київ: Либідь, 1991. - 720 с. 34. Касьянов О. В. Окупаційний режим на Дніпропетровщині в хронологічних довідках місцевих органів влади: Збірник документів / автори-упорядники О. В. Касьянов і Н. В. Киструська - Дніпропетровськ.: Герда, 2010. $380 \mathrm{c}$.

35. Центральний архів Міністерства оборони Російської Федерації. Ф. 228. - Оп. 701. - Спр. 4. - Арк. 316-317. - Режим доступу: https://pamyatnaroda.ru/documents/view/?

36. Шахрайчук I. А. Деякі аспекти діяльності легальних українських громадських об'єднань на Дніпропетровщині в період німецької окупації (19411944 рр.) / I. А. Шахрайчук, М. А. Слободянюк // Наддніпрянський історико-краєзнавчий збірник. - Дніпропетровськ: ДДУ. - № 1. - С. 295-301.

37. Шахрайчук I. А. У тенетах фашистської окупації / I. А. Шахрайчук // Історія Дніпропетровського національного університету. - Дніпропетровськ: ДНУ, 2003. - 232 с.

Надійшла до редкол.: 20. 12. 2017

УДК 94(477)«1941-1945»

DOI: $10.15421 / 231818$

\title{
Із фронтів війни на посаду ректора
}

Савчук В. С.

Дніпровський національний університет імені Олеся Гончара

Розглянуто історію призначення першого (після звільнення Дніпропетровська) ректора Дніпропетровського державного університету та період відновлення його діяльності після повернення з евакуації. Висвітлено життєвий шлях В. М. Полєжаєва, призначеного ректором Дніпропетровського держуніверситету наприкінці війни.

Ключові слова: Дніпропетровськ; війна; держуніверситет; ректор; В. М. Полєжаєв; життєвий шлях

Рассмотрены история назначения (после освобождения Днепропетровска) ректора Днепропетровского государственного университета и период возобновления его деятельности после возвращения из эвакуации. Освещен жизненный путь В. М. Полежаева, назначеного ректором Днепропетровского госуниверситета перед окончанием войны.

Ключевые слова: Днепропетровск; война; госуниверситет; ректор; В. М. Полежаев; жизненный путь

The history of the appointment (after the liberation of Dnepropetrovsk) of the rector of the Dnepropetrovsk State University and the period of his resumption after return from evacuation are considered. The life of V. M. Polezhaev, appointed by the rector of the Dnepropetrovsk State University before the end of the war, is studied. Data on the education he received before entering the Dnipropetrovsk Institute of Public Education are given. 
The pedagogical activity of V. M. Polezhaev was clarified before to his arrival at DINO. His work in postgraduate study, which was held under the scientific supervision of Academician Dinnik, is considered. The background and history of the scientific activity of V. M. Polezhaev prior to the Second World War is covered. It was revealed that his scientific activity during this period was connected with the solution of the flutter problem. In this regard, a brief description of the history of the creation and activities of the aerodynamics group of Dnepropetrovsk State University in the 1930s is given.

The date of protection of V. M. Polezhayev dissertations and themes of dissertational research vas studied. Traced the scientist's military path after the invasion of Nazi Germany into the territory of our country. The main milestones are indicated. The events related to the appointment of V. M. Polezhaev as the rector of Dnepropetrovsk State University are considered. The activities of V. M. Polezhaev are considered in this post, the difficulties and achievements of the university are described in the period when V. M. Polezhaev fulfilled the duties of the rector. The role of V. M. Polezhaev in this process has been determined. Highlights of the activities of the scientist and teacher after leaving the post of the rector are highlighted. It is shown that until throughout his later life, V. M. Polezhaev continued his active work in the field of aerodynamics, the dynamic strength of machines, the study of stresses and deformations. V. M. Polezhaev's contribution to the restoration and creation of the experimental base of the departments of theoretical mechanics and aerodynamics of the Dnepropetrovsk State University is determined. Attention is focused on the fact that this was the first rector of the university in liberated Dnepropetrovsk.

Keywords: Dnipropetrovsk; War; State University; rector; V. M. Polezhaev; life path

Період 1941-1945 рр. був насичений важливими подіями в житті нашої країни. В першу чергу це війна з нацистською Німеччиною. Вона привнесла багато нових сюжетів в історію України, історію діяльності в будь-якій сфері їі життя. Цей переламний моментв історії країни відбився й на діяльності Дніпропетровського університету. Війна призвела до масової евакуації, до чисельної мобілізації викладацького складу, розпорошення наукових кадрів, структурних змін в університеті, що знаходився в евакуації.

3 початком воєнних дій з боку нацистської Німеччини на території нашої держави останній передвоєнний ректор Л. І. Сафронов пішов добровольцем у Червону армію і посада ректора залишалась вільною. Приєднання в евакуації частини Дніпропетровського державного університету на час окупації Дніпропетровська до Чкаловського (Оренбурзького) педагогічного інституту призвело до того, що деякий час Дніпропетровський університет залишався без зайнятої посади ректора. Період відновлення функціонування Дніпропетровського університету після повернення з евакуації розглядався у виданні, присвяченому його історії [1]. Але і в ньому не з'ясовано точно, коли був призначений перший після визволення Дніпропетровська ректор університету й фактично відсутні дані про його життя і діяльність. 
Тож метою даного дослідження є заповнення зазначених вище лакун $\mathrm{i}$ розкриття життєвого шляху першого (після повернення 3 евакуації) ректора Дніпропетровського державного університету.

Університет був евакуйований до м. Чкалов (сучасне місто Оренбург). Туди було вивезено навчальне майно та обладнання. Евакуйовані до Чкалова співробітники Дніпропетровського університету увійшли до складу Чкалівського педагогічного інституту. Також частина викладачів перебувала в різних містах країни в евакуації, значна частина була на фронті [1]. Серед тих, хто перебував на фронті, знаходився й доцент Василь Минайович Полєжаев, який згодом став ректором Дніпропетровського державного університету.

Народився В. М. Полєжаєв 14 січня 1904 р. у с. В.-Серогози Херсонської губернії в родині селянина-середняка, згодом колгоспника. До 1922 р. $з$ села не виїздив, займався сільським господарством у родині батька. За цей час, як він сам пише в автобіографії «без отрыва от отцовского сельского хозяйства учился в различных школах села В. и. Н-Серогозы и окончил 1) земское училище, 2) $2 x$ классное, 3) высшее начальное училище и 3) профпедшколу, проучившись в них 10 лет» [2, арк. 3].

Після закінчення педагогічноїшколи В. М.Полєжаєв почав вчителювати і працював з 1922 р. по 1926 р. в селах Н. Реп’євка та Н.-Серогози Херсонської губернії (області). В цей період за один рік (1923/1924) завершив педагогічну освіту в Мелітопольському педагогічному технікумі. Надалі бажання продовжувати навчання приводить у 1926 р. молоду людину на техно-математичне відділення факультету професійної освіти Дніпропетровського інституту народної освіти (ДІНО). Після реорганізації ДІНО Василь Полєжаєв продовжує з 1930 р. навчання вже на математичному відділенні Дніпропетровського фізико-хіміко-математичного інституту (ДФХМІ), виокремленого з ДІНО.

Вже в студентські роки В. М. Полєжаєв продовжив викладацьку діяльність і залучився до дослідницької роботи. Він керував курсами з підготовки комсомольської молоді до вступу в інститут (з 1926 р.), викладав математику у фабрично-заводському училищі заводу імені Петровського (1928-1930) та механіку у фабрично-заводському училищі Паровозоремонтного заводу (1930-1931), заявив себе як конструктор-дослідник в Дніпродіпросталі (1931-1932).

Після закінчення у 1932 р. ДФХМІ працьовитого юнака взяли на роботу штатним асистентом кафедри теоретичної механіки Дніпропетровського металургійного інституту, який тільки но (у 1930 р.) розпочав свою діяльність. Націй кафедрі він працював до 1937 р. Майже 
одночасно (з 1933 р.) розпочав викладацьку і наукову діяльність на кафедрі теорії пружності й аеродинаміки в Дніпропетровському університеті, який саме у 1933 р. був відновлений як класичний університет. Спочатку як аспірант і завідувач лабораторії, надалі - доцент, помічник ректора, помічник проректора з науково-дослідної роботи.

Науковим керівником В. М. Полєжаєва в аспірантурі був учений зі світовим ім'ям академік О. М. Динник. Під час навчання в аспірантурі, 1933/1934 р. науковець провів на стажуванні в Харківському авіаційному інституті в аеродинамічній лабораторії академіка Г. Ф. Проскури, видатного вченого у галузі аерогідродинаміки і гідромашинобудування. Дуже цікавою виявилася в цей час наукова робота молодого вченого з проблем флатера.

Флатером (від англ. Flutter. - тремтіння, вібрація) називають «сочетание самовозбуждающихся незатухающих изгибных и крутильных колебаний крыла, других элементов конструкции самолёта, главным образом крыла в полёте, либо несущего винта вертолёта, возникающих при достижении некоторой скорости, зависящей от характеристик данного самолёта. Такие колебания способны разрушить самолёт» [5].

Поняттям «флатер», відрізняючись у деяких додаткових характеристиках, фізичну суть цього явища визначають як виникнення різного виду незгасаючих коливань літального апарату, що самозбуджуються. 3 проблемою флатера в першу чергу зіткнулася авіаційна техніка у 1930-х рр. при створенні нових типів літаків із підвищеними льотними характеристиками: вантажопідйомність, швидкість, вага тощо. «Енциклопедія техніки» інформує, що в Німеччині у 1935-1943 рр. відбулося не менше 150 випадків аварій і катастроф від флатера. Тобто, проблема флатера була дуже гострою та актуальною, $\mathrm{i}$ відсутність іiі розв'язання стримувала розвиток літакобудування.

Дослідження проблеми флаттера велися звичайно і в СРСР. В першу чергу в ЦАГІ. Наші дослідження показали, що в проблемі флаттера $є$ й дніпропетровський слід [4]. Тобто мала місце участь в розробці цієї проблеми вчених дніпропетровських вузів. Багато 3 них належали до школи нашого земляка, видатного вченого в галузі механіки і теорії пружності, академіка АН СРСР О. М. Динника, засновника української школи з теорії пружності [3]. Серед його учнів виявилися й ті, хто був причетний до розробки проблеми флатера.

1938 р. став роком, коли відбувся ряд важливих подій, що зіграли велику роль в житті дніпропетровської групи вчених-механіків. Об'єднання молодих вчених виникло у 1934 р. Позитивною подією стало затвердження Всесоюзним комітетом зі справ вищої школи 
Групи аеродинаміки як самостійної одиниці в складі кафедри теорії пружності та аеродинаміки ДДУ.

Група аеродинаміки ДДУ під керівництвом проф. В. П. Лискова (учня О.Динника) досягла значних успіхів [4]. Займаючись проблемою вібрацій ця група (В. П. Лисков, О. І. Пеньков, Л. Т. Афендик, В. Г. Тульчинський, В. Г. Сенченко, О. О. Мороз й інші) прийняла участь у створенні літака «ЦАГІ-25», на якому здійснив переліт через Північний полюс Валерій Чкалов. За завданням ЦАГІ вони розрахували крила цього літака на вібрацію. Цікавим є факт, що підтримка з боку ЦАГІ була отримана під час дискусії 7 березня 1939 р. на розширеному засіданні Ради ЦАГІ за участю відомих спеціалістів та авіаконструкторів СРСР, на якому В. П. Лисков та Б. Д. Франк довели своє право працювати над проектом паралельно з групою вібрацій ЦАГІ. ЦАГІ забезпечив цю групу складною апаратурою для виконання досліджень.

Багато хто з членів цієї групи захистив дисертаційні роботи. У складі групи працювали не тільки співробітники Дніпропетровського держуніверситету, але й Дніпропетровського металургійного інституту. Серед них був і В. М. Полєжаєв, який у 1937 р. закінчив аспірантуру і в тому ж році успішно захистив дисертацію на здобуття наукового ступеня кандидата фізико-математичних наук за темою «Вібрація крила літака постійного перерізу». Саме після закінчення аспірантури В. М. Полєжаєв переходить з ДМЕТІ до Дніпропетровського державного університету на постійну роботу і працює в ньому до 1941 р (до початку війни з нацистською Німеччиною). У 1939 р. В. М. Полєжаєв отримав звання доцента по кафедрі теорії пружності і аеродинаміки. У тому ж році став членом ВКП(б).

3 липня 1941 р. В. М. Полєжаєв знаходився на фронті й перебував там до 20 січня 1943 р. Спочатку у винищувальному батальйоні, потім був політруком батареї 776 артилерійського полку 244-ої стрілецької дивізії. Воював під Сталінградом, отримав контузію. Після уральського шпиталю місяць перебував у відпустці в м. Янги-Юль Ташкентської області й був звільнений комісією Середньо-Азіатського військового округу з лав радянської армії на три місяці.

В армію його вже не повернули. У березні-серпні 1943 p. В. М. Полєжаєв працював інструктором у міському комітеті КП(б) Узбекистану, звідки його за викликом ЦК ВКП(б) відрядили в Україну. В Харкові, де тимчасово знаходився уряд радянської України, він за наказом заступника наркомосвіти УРСР отримав призначення 3 04.09.1943 р. на посаду виконуючого обов'язки ректора Дніпропетровського державного університету. Зрештою, його праця під час вій- 
ни була відмічена медаллю «За перемогу над Німеччиною у Великій вітчизняній війні» та медаллю «За доблесну працю у Великій вітчизняній війні».

3 часом було звільнено Павлоград і радянські органи влади, а разом з ними і керівництво Дніпропетровського університету, перебралися до Павлограда. Ректорат розташовувався у невеличкому будинку на околиці міста. Як писав у автобіографії В. М. Полєжаєв, «после освобождения Павлограда с ноября 1943 г. организовал восстановление работы Днепропетровского государственного университета в г. Днепропетровске после его освобождения» [2, арк. 23]. Так скромно оцінив свою роботу на посаді ректора В. М. Полєжаєв. І дійсно. Нi про які наукові здобутки та інші перемоги мова йти не могла. Йшла повсякденна робота зі встановлення місця перебування евакуйованих викладачів, тих, хто знаходився на фронті, листування з ними, з'ясування прізвищ загиблих на війні тощо. Але ця повсякденна робота стала запорукою того, що університет почав своє відновлення. Разом із частинами радянської армії ректорат все більше на-ближався до Дніпропетровська. 3 Павлограда він переїхав до Нижньодніпровська. А 25 жовтня 1943 р. прибув до Дніпропетровська.

Головним завданням ректорату й усіх співробітників університету на чоліз В. М. Полєжаєвим стало забезпечення початкузанять. Що при майже повній відсутності приміщень, нестачі викладачів, наявності гострої продовольчої проблеми було надзвичайно важким завданням. Тим не менш, уже 6 листопада 1943 р. в університеті відбулися перші заняття. 3 січня 1944р. вонисталирегулярними.Буловідновленосімфакультетів:фізико-математичний, біологічний, хімічний, геолого-географічний, історичний, філологічний.Іфакультетзахіднихмовталітератури[1,с.123].Уквітні1944p. В. М. Полєжаєв, виконавши свою місію, склав повноваження виконуючого обов'язки ректора Дніпропетровського державного університету новопризначеному ректору - Н. З. Хмарському.

Надалі В. М. Полєжаєв працював в університеті до 1967 р. на посаді доцента кафедри теоретичної механіки. Брав активну участь у навчально-науковій, громадській і партійній роботі. Активно займався відновленням зруйнованих наукових лабораторій та організацією нових. В одній із його післявоєнних характеристик зазначалося, що він «виявив ініціативу в організації експериментальної бази кафедри теоретичної механіки і кафедри аеродинаміки ДДУ (що існувала до 1941 р.)» [2, арк. 13]. Його наукові інтереси у післявоєнний період зосереджувалися головним чином у галузі «експериментальних досліджень з питань аеродинаміки і напружень та деформацій несучої здатності і динамічної міцності ма- 
шин і механізмів електротензометричними методами в заводських умовах» [1, арк. 18]. Таким був перший ректор університету у звільненому Дніпропетровську. Головною його заслугою на посаді ректора стало швидке відновлення в жорстких умовах воєнного часу функціонування Дніпропетровського державного університету.

\section{БІБЛІОГРАФІЧНІ ПОСИЛАННЯ}

1. Історія Дніпропетровського національного університету / Голова редколегії М. В. Поляков. - 4-те вид., переробл. і доповн. - Дніпропетровськ: Вид-во ДНУ, 2008. - 308 с.

2. Полежаев Василий Минаевич // Архів Дніпровського національного університету імені Олеся Гончара. - Ф. 1, оп. 1, спр. 2847. - 42 л.

3. Развитие механики в СССР 1917-1967 / Ред.: А. Ю. Ишлинский. - М., 1967. - 368 с.

4. Савчук В. С. Днепропетровский след в истории решения проблемы флаттера / В. С. Савчук // Матеріали VII наукових читань «Дніпровська орбіта - 2012». - Дніпропетровськ, 2012. - С. 74-79.

5. Флаттер // Большая советская энциклопедия. - М.: Советская энциклопедия, 1977. - Т. 27. Надійшла до редкол.: 06.04.2018

Особливості організації навчального процесу та адаптації шкільної молоді до мирного життя в 1944-1945 рр. (на матеріалах Дніпропетровської спецшколи ВПС)

\section{Бурмага В. П., Уткін П. Л.}

\section{Дніпровський національний університет імені Олеся Гончара}

Спираючись на архівний матеріал, розкрито особливості організації навчального процесу у Дніпропетровській спеціальній школі ВПС у першому після відновлення роботи 1944-1945 навчальному році.

Ключові слова: спецшкола; навчальний процес; засвоєння програми; успішність; гуртки; навчальні матеріали; табірний збір

Опираясь на архивный материал, раскрыто особенности организации учебного процесса в Днепропетровской спецшколе ВВС в первый после возобновления работы 1944-1945 учебный год.

Ключевые слова: спецшкола; учебный процесс; усвоение программы; успеваемость; кружки; учебные материалы; лагерный сбор

Relying on archival material, there were disclosed the peculiarities of educational process organization in Dnepropetrovsk Special Military School of Air Force in the first academic year after its restoration (1944-1945). It has been revealed that the school year has begun with a delay in the conditions of low level of school provision. There was lack of textbooks and other teaching materials. Due to being in occupation, the cadets were poorly trained, because of what teachers had 